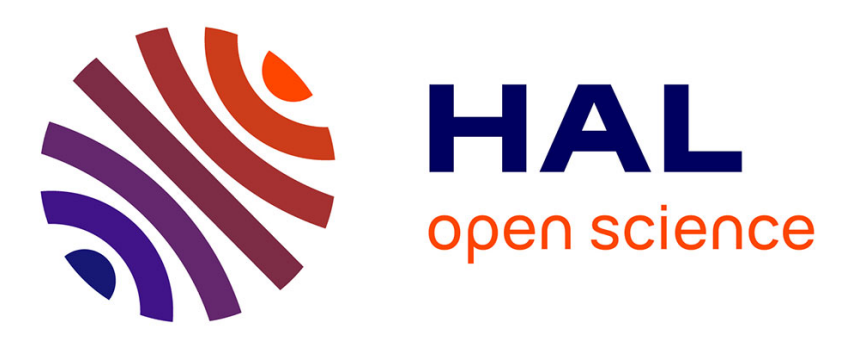

\title{
Octahedral niobium cluster-based solid state halides and oxyhalides: effects of the cluster condensation via an oxygen ligand on electronic and magnetic properties
} Bruno Fontaine, Stéphane Cordier, Régis Gautier, Fakhili Gulo, Jean-François Halet, Berislav Perić, Christiane Perrin

\section{To cite this version:}

Bruno Fontaine, Stéphane Cordier, Régis Gautier, Fakhili Gulo, Jean-François Halet, et al.. Octahedral niobium cluster-based solid state halides and oxyhalides: effects of the cluster condensation via an oxygen ligand on electronic and magnetic properties. New Journal of Chemistry, 2011, 35 (10), pp.2245-2252. 10.1039/C1NJ20377K . hal-00860286

\section{HAL Id: hal-00860286 https://hal.science/hal-00860286}

Submitted on 10 Sep 2013

HAL is a multi-disciplinary open access archive for the deposit and dissemination of scientific research documents, whether they are published or not. The documents may come from teaching and research institutions in France or abroad, or from public or private research centers.
L'archive ouverte pluridisciplinaire HAL, est destinée au dépôt et à la diffusion de documents scientifiques de niveau recherche, publiés ou non, émanant des établissements d'enseignement et de recherche français ou étrangers, des laboratoires publics ou privés. 


\title{
Octahedral niobium cluster-based solid state halides and oxyhalides: effects of the cluster condensation via an oxygen ligand on electronic and magnetic properties $\dagger$
}

\author{
Bruno Fontaine, ${ }^{a}$ Stéphane Cordier, ${ }^{* a}$ Régis Gautier, ${ }^{* a}$ Fakhili Gulo, ${ }^{a b}$ \\ Jean-François Halet, ${ }^{a}$ Berislav Peric ${ }^{a c}$ and Christiane Perrin ${ }^{* a}$
}

Received (in Montpellier, France) 29th April 2011, Accepted 1st June 2011

DOI: $10.1039 / \mathrm{c} 1 \mathrm{nj} 20377 \mathrm{k}$

The influences of an oxygen ligand on the structural, magnetic and electronic properties of

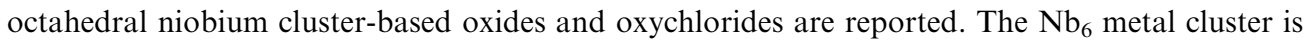
edge-bridged by twelve inner ligands and additionally bonded to six apical ligands to form $\mathrm{Nb}_{6} \mathrm{~L}_{12}^{\mathrm{i}} \mathrm{L}_{6}^{\mathrm{a}}$ units $(\mathrm{L}=\mathrm{Cl}, \mathrm{O})$ wherein oxygen and chlorine are perfectly ordered. Oxygen favours the interconnection of clusters via double $\mathrm{O}^{\mathrm{i}-\mathrm{a}} / \mathrm{O}^{\mathrm{a}-\mathrm{i}}$ bridges in a similar way to the double $\mathrm{S}^{\mathrm{i}-\mathrm{a}} / \mathrm{S}^{\mathrm{a}-\mathrm{i}}$ bridges found in Chevrel phases based on face capped $\mathrm{Mo}_{6} \mathrm{~L}_{8}^{\mathrm{i}} \mathrm{L}_{6}^{\mathrm{a}}$ units. Periodic density functional theory (DFT) calculations confirm that increasing the number of inner oxygen ligands at the expense of chlorine atoms favours the 14 metal-electron (ME) count per octahedral cluster unit. It is also shown that weak interactions occur between neighbouring clusters. Indeed, magnetic measurements performed on $\mathrm{A}_{x} \mathrm{Nb}_{6} \mathrm{Cl}_{12} \mathrm{O}_{2}(\mathrm{~A}=\mathrm{Rb}, x=0.816(8) ; \mathrm{A}=\mathrm{Cs}, x=1)$ series containing $15-\mathrm{ME}$ species evidence antiferromagnetic interactions at low temperatures. Broken-symmetry DFT calculations of exchange parameters within spin dimer analysis confirm the experimental results.

\section{Introduction}

The term metal atom cluster, introduced by F. A. Cotton in the early 1960's, defines a finite group of metal atoms held together via metal-metal bonds. ${ }^{1}$ Typical examples are found for octahedral nano-sized metallic clusters of transition elements which are easily obtained by solid state synthesis at high temperatures. They are associated with halogen or chalcogen ligands to form $\left[\left(\mathrm{M}_{6} \mathrm{~L}_{12}^{\mathrm{i}}\right) \mathrm{L}_{6}^{\mathrm{a}}\right]^{n-}$ and $\left[\left(\mathrm{M}_{6} \mathrm{~L}_{8}^{\mathrm{i}}\right) \mathrm{L}_{6}^{\mathrm{a}}\right]^{n-}$ units $(\mathrm{a}=$ apical, $\mathrm{i}=$ inner). ${ }^{2}$ As sketched in Fig. $1, \mathrm{M}_{6}$ clusters are bonded to six terminal ligands $\left(\mathrm{L}^{\mathrm{a}}\right)$ in both kinds of units but they are edge-bridged by twelve inner ligands $\left(\mathrm{L}^{\mathrm{i}}\right)$ in the $\left[\left(\mathrm{M}_{6} \mathrm{~L}_{12}^{\mathrm{i}}\right) \mathrm{L}_{6}^{\mathrm{a}}\right]^{n-}$ unit $(\mathrm{M}=\mathrm{Nb}, \mathrm{Ta}, \mathrm{W})$ and face-capped by eight inner ligands $\left(\mathrm{L}^{\mathrm{i}}\right)$ in the $\left[\left(\mathrm{M}_{6} \mathrm{~L}_{8}^{\mathrm{i}}\right) \mathrm{L}_{6}^{\mathrm{a}}\right]^{n-}$ unit $(\mathrm{M}=\mathrm{Mo}, \mathrm{W}, \mathrm{Re})$. The intrinsic properties of $\mathrm{M}_{6}$ cluster units - one- or two-electron reversible redox process, magnetism and luminescence - depend on the

\footnotetext{
${ }^{a}$ Sciences Chimiques de Rennes, UMR 6226, CNRS-Université de

Rennes 1-Ecole Nationale Supérieure de Chimie de Rennes,

CS 50837, 35708 Rennes Cedex 7, France,

E-mail:rgautier@ensc-rennes.fr, stephane.cordier@univ-rennes1.fr, christiane.perrin@univ-rennes1.fr; Fax: + 3322323 8199;

Tel: + 33223238122

${ }^{b}$ Sriwijaya University, Department of Chemical Education, Palembang, Indonesia

${ }^{c}$ Division of Materials Chemistry, Ruđer Bosković Institute,

Bijenička cesta 54, HR-10000 Zagreb, Croatia

$\dagger$ We dedicate this work to Didier Astruc on the occasion of his 65th birthday.
}
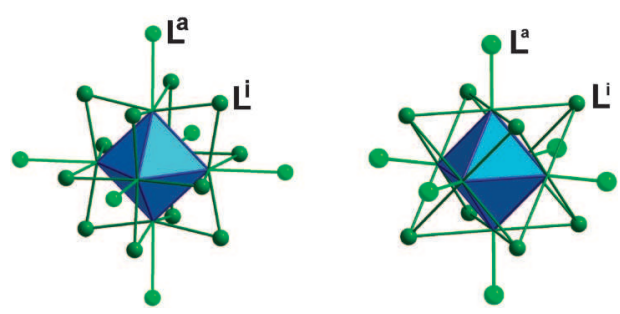

Fig. 1 Representation of edge-bridged $\left(\mathrm{M}_{6} \mathrm{~L}_{12}^{\mathrm{i}}\right) \mathrm{L}_{6}^{\mathrm{a}}$ (left) and facecapped $\left(\mathrm{M}_{6} \mathrm{~L}_{8}^{\mathrm{i}}\right) \mathrm{L}_{6}^{\mathrm{a}}$ (right) units.

nature of the metal and the ligands. The solubilisation of $\mathrm{M}_{6}$ solid state compounds provides $\left[\left(\mathrm{M}_{6} \mathrm{~L}_{12}^{\mathrm{i}}\right) \mathrm{L}_{6}^{\mathrm{a}}\right]^{n-}$ or $\left[\left(\mathrm{M}_{6} \mathrm{~L}_{8}^{\mathrm{i}}\right) \mathrm{L}_{6}^{\mathrm{a}}\right]^{n-}$ discrete building blocks in solution with specific physicostructural properties that can be used, via soft chemistry routes, in the design of hybrid organic/inorganic assemblies, ${ }^{3}$ organometallic stars and dendrimers, ${ }^{4-6}$ luminescent nanoparticles $^{7,8}$ liquid crystals $^{9,10}$ or coordination polymeric framework ${ }^{11-13}$ as well as molecular junctions. ${ }^{14,15}$

The structures of niobium octahedral cluster halides are built up from either discrete or interconnected units in one, two or three directions of space (noted 1-, 2- and 3D respectively) by common $\mathrm{L}^{\mathrm{a}-\mathrm{a}}$ apical ligands (1-D: $\mathrm{Cs}_{2} \mathrm{Nb}_{6} \mathrm{Br}_{5} \mathrm{~F}_{12}{ }^{16}\left(\mathrm{Cs}_{2} \mathrm{Nb}_{6} \mathrm{Br}_{5}^{\mathrm{i}} \mathrm{F}_{7}^{\mathrm{i}} \mathrm{F}_{2 / 2}^{\mathrm{a}-\mathrm{a}} \mathrm{F}_{4}^{\mathrm{a}}\right.$ according to the Schäfer notation), ${ }^{2} \quad$ 2-D: $\quad \mathrm{Li}_{2} \mathrm{Nb}_{6} \mathrm{Cl}_{16} \quad\left(\mathrm{Li}_{2} \mathrm{Nb}_{6} \mathrm{Cl}_{12}^{\mathrm{i}} \mathrm{Cl}_{4 / 2}^{\mathrm{a}-\mathrm{a}} \mathrm{Cl}_{2}\right),{ }^{17} \quad$ 3-D: $\mathrm{Nb}_{6} \mathrm{~F}_{15}\left(\mathrm{Nb}_{6} \mathrm{~F}_{12}^{\mathrm{i}} \mathrm{F}_{6 / 2}^{\mathrm{a}-\mathrm{a}}\right)^{18}$ and $\mathrm{Na}_{2} \mathrm{NbF}_{6}-\mathrm{Nb}_{6} \mathrm{~F}_{12-\mathrm{x}}^{\mathrm{i}} \mathrm{X}_{\mathrm{x}}^{\mathrm{i}} \mathrm{F}_{6}^{\mathrm{a}}(\mathrm{X}=$ $\mathrm{Cl}, \mathrm{Br})^{19,20}$ series). In the $\mathrm{Nb}_{6} \mathrm{~L}_{15} 3$-D compounds $\left(\mathrm{Nb}_{6} \mathrm{~L}_{12}^{\mathrm{i}} \mathrm{L}_{6 / 2}^{\mathrm{a}-\mathrm{a}}\right)$, 
all the six apical ligands of the units are involved in cluster interconnections. This type of connection does not enable strong electronic interactions between units that keep a molecular character. In the binary chloride $\mathrm{Nb}_{6} \mathrm{Cl}_{14},{ }^{21}$ written as $\mathrm{Nb}_{6} \mathrm{Cl}_{10}^{\mathrm{i}}$ $\mathrm{Cl}_{2 / 2}^{\mathrm{i}-\mathrm{a}} \mathrm{Cl}_{4 / 2}^{\mathrm{a}-\mathrm{a}} \mathrm{Cl}_{2 / 2}^{\mathrm{a}-\mathrm{i}}$, the six apical ligands as well as two of the twelve inner ligands are involved in cluster interconnections leading to double $\mathrm{Cl}^{\mathrm{i}-\mathrm{a}} / \mathrm{Cl}^{\mathrm{a}-\mathrm{i}}$ bridges. Because of the steric hindrance within the $\mathrm{Nb}_{6} \mathrm{Cl}_{12}^{\mathrm{i}} \mathrm{Cl}_{6}^{\mathrm{a}}$ building units, the $\mathrm{Nb}-\mathrm{Cl}^{\mathrm{a}-\mathrm{i}}$ and $\mathrm{Nb}-\mathrm{Cl}^{\mathrm{i}-\mathrm{a}}$ bond lengths are longer than the $\mathrm{Nb}-\mathrm{Cl}^{\mathrm{a}-\mathrm{a}}$ ones and consequently do not engender stronger interactions between units. Smaller ligands than $\mathrm{Cl}$ might strengthen electronic interactions between $\mathrm{M}_{6} \mathrm{~L}_{18}$ units. Among halogens and chalcogens, only fluorine and oxygen satisfy this condition. It turns out that in $\mathrm{Nb}_{6}$ cluster chemistry, the fluorine element leads to compounds with $\mathrm{F}^{\mathrm{a}-\mathrm{a}}$ bridges involving apical ligands and not to $\mathrm{F}^{\mathrm{a}-\mathrm{i}}, \mathrm{F}^{\mathrm{i}-\mathrm{a}}$ or even $\mathrm{F}^{\mathrm{i}-\mathrm{i}}$ connections. The decrease of the size of the whole $\mathrm{Nb}_{6} \mathrm{~L}_{18}$ units in the fluorinated clusters compared to chlorinated ones reduces the distance between nearest neighbouring clusters and increases magnetic interactions between them. Recent ${ }^{19} \mathrm{~F}$ nuclear magnetic resonance and muon spin resonance studies have evidenced antiferromagnetic interactions around $6 \mathrm{~K}$ for $\mathrm{Nb}_{6} \mathrm{~F}_{15}{ }^{22}$ to be compared to $2 \mathrm{~K}$ for $\mathrm{LuNb}_{6} \mathrm{Cl}_{18}{ }^{23}$ Oxygen appears much more favourable to intimate condensation of units than fluorine through $\mathrm{O}^{\mathrm{a}-\mathrm{a}}$ but also $\mathrm{O}^{\mathrm{i}-\mathrm{a}}$ and $\mathrm{O}^{\mathrm{i}-\mathrm{i}}$ bridges as illustrated by the examples of $\mathrm{Nb}_{10} \mathrm{Cl}_{16} \mathrm{O}_{7}{ }^{24}$ or $\mathrm{CsNb}_{6} \mathrm{Cl}_{12} \mathrm{O}_{2}{ }^{25}$ The covalent radius size of $\mathrm{O}$ and $\mathrm{F}$ being close $(0.73$ vs. 0.71$)$, this feature must be attributed to their difference of valence and electronegativity. The electronic interactions are expected to be stronger in oxides than in halides owing to short $\mathrm{Nb}-\mathrm{O}$ bond lengths.

In this work, we propose to evidence the electronic influence of the oxygen ligand in the $\mathrm{Nb}_{6}$ cluster chemistry on the basis of the research devoted these last few years to $\mathrm{Nb}_{6} \mathrm{~L}_{18}$ based compounds. Since the discovery of the first $\mathrm{Nb}_{6}$ oxyhalide, namely $\mathrm{ScNb}_{6} \mathrm{Cl}_{13} \mathrm{O}_{3},{ }^{26}$ several $\mathrm{Nb}_{6}$ oxyhalides have been reported. An interesting finding is that the replacement of inner halogen by the oxygen ligand favours the condensation of the $\mathrm{M}_{6} \mathrm{~L}_{12}^{\mathrm{i}} \mathrm{L}_{6}^{\mathrm{a}}$ units by double $\mathrm{O}^{\mathrm{i}-\mathrm{a}} / \mathrm{O}^{\mathrm{a}-\mathrm{i}}$ or simple $\mathrm{O}^{\mathrm{i}-\mathrm{i}}$ bridges. Our study will be focussed on $\mathrm{A}_{x} \mathrm{Nb}_{6} \mathrm{Cl}_{12} \mathrm{O}_{2}(\mathrm{~A}=\mathrm{Cs}, x=1 ; 25 \mathrm{~A}=$ $\mathrm{Rb}, x=0.816(8)),{ }^{27,28} \mathrm{Na}_{0.21} \mathrm{Nb}_{6} \mathrm{Cl}_{10.5} \mathrm{O}_{3},{ }^{30} \mathrm{Ti}_{2} \mathrm{Nb}_{6} \mathrm{O}_{12},{ }^{31}$ and $\mathrm{Na}_{2}\left(\mathrm{Sc}_{4} \mathrm{Nb}_{2}\right)\left(\mathrm{Nb}_{6} \mathrm{O}_{12}\right)_{3}{ }^{32}$ that are characterized by double $\mathrm{O}^{\mathrm{i}-\mathrm{a}} / \mathrm{O}^{\mathrm{a}-\mathrm{i}}$ bridges in 1,2 and 3 directions, respectively. A schematic representation of the connection schemes of octahedral metallic units in these compounds is sketched in Fig. $2{ }^{33}$ These $\mathrm{O}^{\mathrm{i}-\mathrm{a}} / \mathrm{O}^{\mathrm{a}-\mathrm{i}}$ bridges in $\mathrm{Nb}_{6}$ compounds remind those observed in $\mathrm{Mo}_{6} \mathrm{~L}_{8}$ chalcogenides $\left(\mathrm{L}=\mathrm{S}\right.$, Se, Te) written as $\mathrm{Mo}_{6} \mathrm{~L}_{2}^{\mathrm{i}} \mathrm{L}_{6 / 2}^{\mathrm{i}-\mathrm{a}} \mathrm{L}_{6 / 2}^{\mathrm{a}-\mathrm{i}}$ that are based on $\mathrm{Mo}_{6} \mathrm{~L}_{8}^{\mathrm{i}} \mathrm{L}_{6}^{\mathrm{a}}$ face-capped units. ${ }^{34}$ Despite similar topologies, the physical properties of molybdenum cluster chalcogenides are different from those of niobium cluster oxyhalides and oxides. Indeed, molybdenum chalcogenides exhibit a wide range of physical properties such as superconductivity at high critical magnetic fields, ${ }^{34}$ catalysis ${ }^{35}$ redox intercalation process ${ }^{36}$ as well as thermoelectric properties. ${ }^{37} \mathrm{On}$ the other hand, the physical properties of niobium oxides and oxyhalides are restricted to paramagnetism, antiferromagnetism or semiconducting behaviours.

We present an overview of the electronic structures - using calculations based on density functional theory (DFT) of the
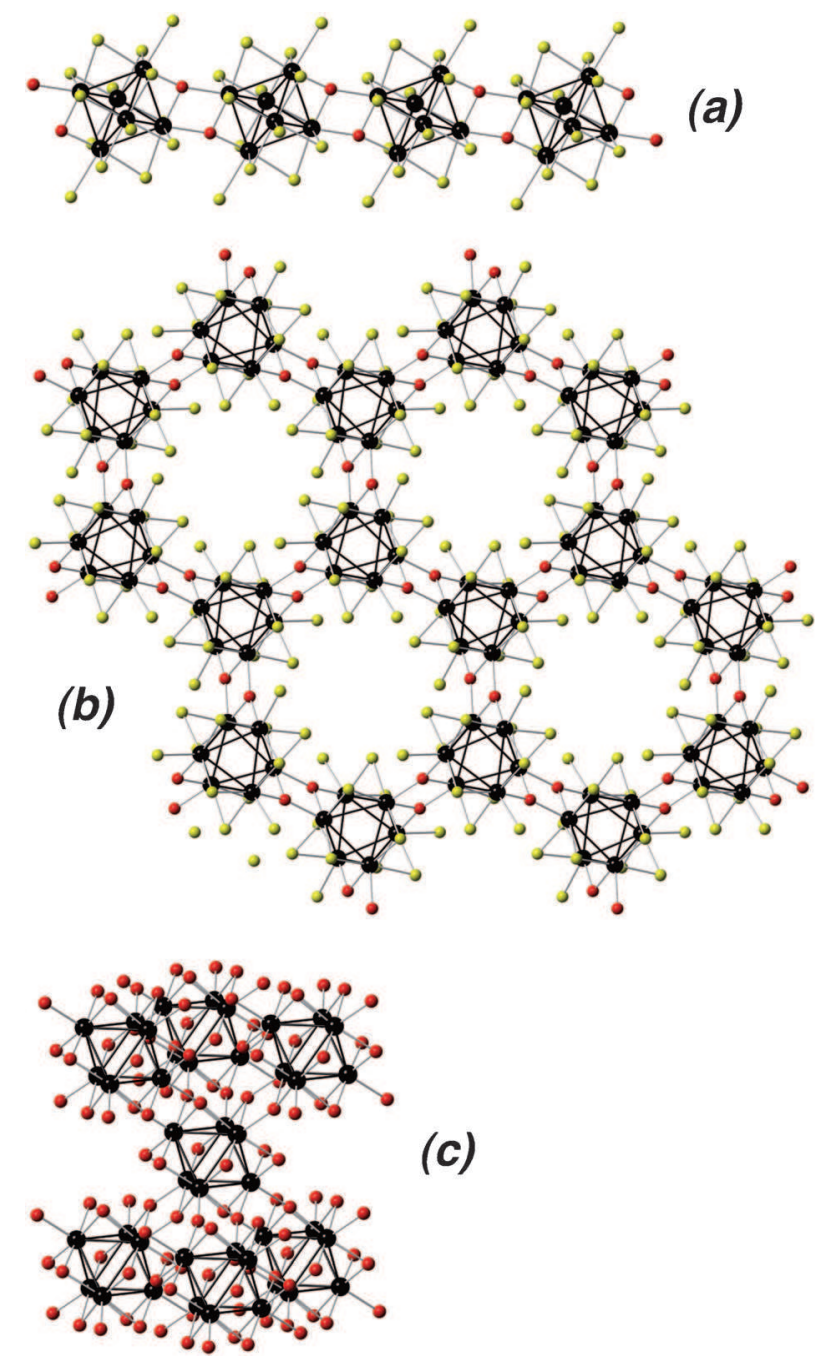

Fig. 2 Connection schemes of $\mathrm{Nb}_{6} \mathrm{~L}_{12}^{\mathrm{i}} \mathrm{L}_{6}^{\mathrm{a}}$ octahedral cluster units via double $\mathrm{O}^{\mathrm{i}-\mathrm{a}} / \mathrm{O}^{\mathrm{a}-\mathrm{i}}$ bridges in some oxyhalides and oxides: ${ }^{33}$ (a) 1-D connections in $\mathrm{A}_{x} \mathrm{Nb}_{6} \mathrm{Cl}_{12} \mathrm{O}_{2}$ ( $\mathrm{A}=$ alkaline cations or In), (b) 2-D connections in $\mathrm{Na}_{0.21} \mathrm{Nb}_{6} \mathrm{Cl}_{10.5} \mathrm{O}_{3}$, (c) 3-D connections in $\mathrm{Ti}_{2} \mathrm{Nb}_{6} \mathrm{O}_{12}$ and $\mathrm{Na}_{2}\left(\mathrm{Sc}_{4} \mathrm{Nb}_{2}\right)\left(\mathrm{Nb}_{6} \mathrm{O}_{12}\right)_{3}$. Black, dark grey and light grey spheres are $\mathrm{Nb}, \mathrm{O}$, and $\mathrm{Cl}$, respectively.

aforementioned oxyhalides that exhibit double $\mathrm{O}^{\mathrm{i}-\mathrm{a}} / \mathrm{O}^{\mathrm{a}-\mathrm{i}}$ interunit connections and the consequences on their physical properties. Subsequently, the magnetic properties of $\mathrm{CsNb}_{6} \mathrm{Cl}_{12} \mathrm{O}_{2}$ and $\mathrm{Rb}_{0.816(8)} \mathrm{Nb}_{6} \mathrm{Cl}_{12} \mathrm{O}_{2}$ are studied and discussed both experimentally and theoretically.

\section{Results}

\section{Electronic structure calculations}

The electronic structures of $\mathrm{M}_{6} \mathrm{~L}_{12}^{\mathrm{i}} \mathrm{L}_{6}^{\mathrm{a}}$ clusters were studied by several authors using quantum chemical calculations. ${ }^{38}$ Indeed, the molecular orbital (MO) diagram of such octahedral clusters shows a set of seven metal-based levels (the irreducible representations of which are $a_{1 g}, t_{2 g}$, and $t_{1 u}$ within $O_{h}$ symmetry) that are clearly low in energy and are bonding in character. An additional MO of $a_{2 u}$ symmetry lies higher in energy. This MO shows both $\mathrm{M}-\mathrm{M}$ bonding and $\mathrm{M}-\mathrm{L}^{\mathrm{i}}$ antibonding character. 
Its energy depends on the nature of metal and ligand atoms. For niobium octahedral cluster halides, the $\mathrm{M}-\mathrm{M}$ bonding character dominates the $\mathrm{M}-\mathrm{L}$ antibonding one in such a way that this MO is low enough in energy to be occupied. This leads to $16-\mathrm{ME}$ species. For the $\mathrm{Nb}_{6} \mathrm{O}_{18}$ cluster, the $\mathrm{Nb}-\mathrm{O}$ antibonding character overtakes, disfavouring occupation of this orbital, favouring thus the count of $14 \mathrm{ME}$.

Different cluster interlinkings are encountered depending upon the halogen/oxygen ratio. ${ }^{33}$ Periodic DFT calculations have been carried out to analyze how condensation of units through $\mathrm{O}^{\mathrm{i}-\mathrm{a}} / \mathrm{O}^{\mathrm{a}-\mathrm{i}}$ bridges influences the electronic structures of these compounds. The total density of states (DOS) and $\mathrm{Nb}$-projected DOS curves for $\mathrm{RbNb}_{6} \mathrm{Cl}_{12} \mathrm{O}_{2}$ which contains 15-ME $\left[\left(\mathrm{Nb}_{6} \mathrm{Cl}_{10}^{\mathrm{i}} \mathrm{O}_{2 / 2}^{\mathrm{i}-\mathrm{a}}\right) \mathrm{Cl}_{4 / 2}^{\mathrm{a}-\mathrm{a}} \mathrm{O}_{2 / 2}^{\mathrm{a}-\mathrm{i}}\right]^{-}$units are shown in Fig. 3. The DOS curve exhibits narrow peaks that show weak intercluster three-dimensional interactions in the compound. The Fermi level cuts a narrow peak of DOS that lies in the middle of a large energy gap of $1.5 \mathrm{eV}$. It is smaller than that previously computed using extended Hückel-tight binding (EH-TB) calculations. ${ }^{39}$ As shown by the COHP curves sketched in Fig. 3, this DOS peak evidences some intra- $\mathrm{Nb}_{6}$ cluster $\mathrm{Nb}-\mathrm{Nb}$ bonding character whereas it is non-bonding between niobium atoms belonging to neighbouring $\mathrm{Nb}_{6}$ clusters. Assuming a rigid band model, the ME count that optimizes the metal-metal bonding in this model compound would therefore be reached with a one electron reduction, i.e., 16

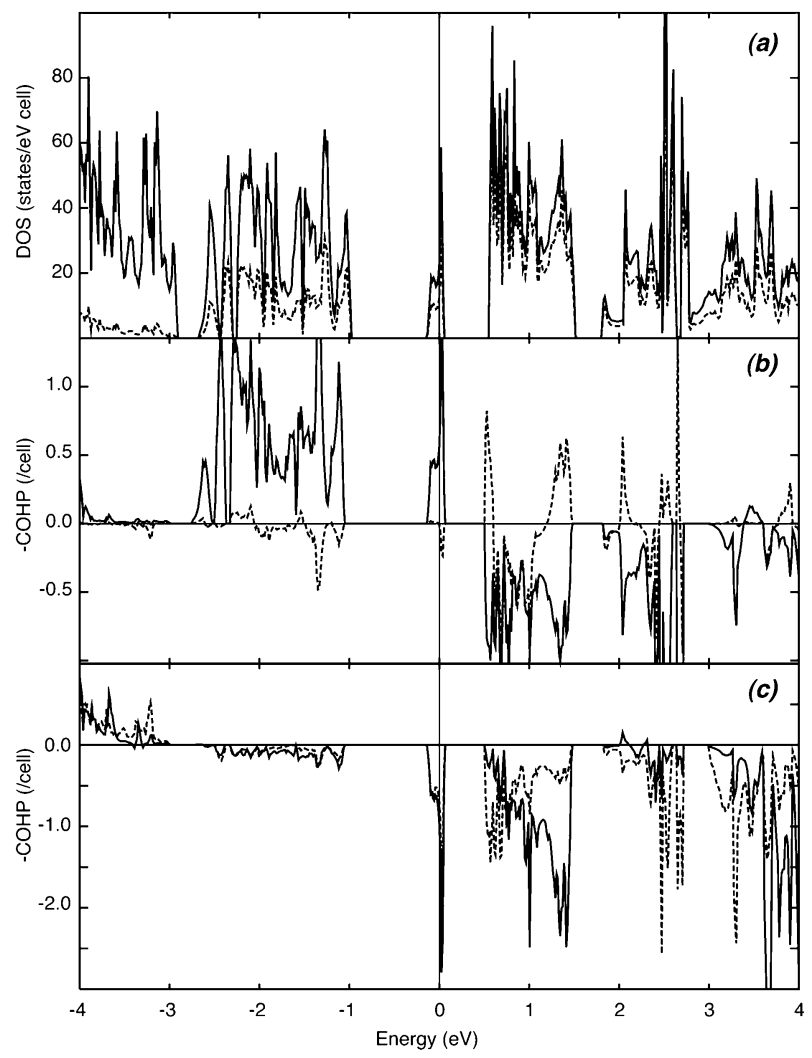

Fig. 3 LMTO calculations for $\mathrm{RbNb}_{6} \mathrm{Cl}_{12} \mathrm{O}_{2}$ : (a) total DOS (solid) and $\mathrm{Nb}$ contribution (dotted), (b) intracluster $\mathrm{Nb}-\mathrm{Nb}$ ranging from $2.804 \AA$ to $3.039 \AA$ (solid) and intercluster $\mathrm{Nb}-\mathrm{Nb}$ (3.345 $\AA$, dotted) COHP curves, (c) $\mathrm{Nb}-\mathrm{O}^{\mathrm{i}}$ ranging from $1.97 \AA$ to $1.99 \AA$ (solid) and $\mathrm{Nb}-\mathrm{Cl}^{\mathrm{i}}$ ranging from $2.434 \AA$ to $2.525 \AA$ (dotted) COHP curves.
ME. Since the interaction of the monovalent cation atoms with the cluster network is mainly ionic, substitution of monovalent atoms with divalent atoms such as alkaline-earth metals would lead to this optimal ME count. Such a reduction would affect the $\mathrm{Nb}-\mathrm{L}^{\mathrm{i}}$ bonds because of the $\mathrm{Nb}-\mathrm{L}^{\mathrm{i}}$ antibonding character of the DOS peak at the Fermi level (Fig. 3). In contrast, $\mathrm{Nb}-\mathrm{L}^{\mathrm{a}}$ bonds should not be affected since apical ligands poorly contribute to DOS peaks that lie in the vicinity of the Fermi level. Diamagnetic and semiconducting properties are foreseen for such a hypothetical compound.

A previous theoretical study using molecular DFT calculations carried out in our group ${ }^{40}$ was devoted to the electronic structure of the $\mathrm{Nb}_{6} \mathrm{Cl}_{17} \mathrm{O}$ cluster, present in $\mathrm{Cs}_{2} \mathrm{LuNb}_{6} \mathrm{Cl}_{17} \mathrm{O},{ }^{41}$ and to different isomers of $\mathrm{Nb}_{6} \mathrm{Cl}_{15} \mathrm{O}_{3}$, present in $\mathrm{Cs}_{2} \mathrm{UNb}_{6} \mathrm{Cl}_{15} \mathrm{O}_{3}{ }^{42}$ and $\mathrm{ScNb}_{6} \mathrm{Cl}_{13} \mathrm{O}_{3} .{ }^{26}$ It was shown that replacing one halogen ligand by oxygen in the former does not modify much the electronic structure of these species. In contrast, in the case of $\mathrm{Nb}_{6} \mathrm{Cl}_{15} \mathrm{O}_{3}$ where three among the twelve capping ligands are oxygen, the $a_{2 u} \mathrm{MO}$ is destabilized. This makes 16-ME $\mathrm{Nb}_{6} \mathrm{Cl}_{15} \mathrm{O}_{3}$ units unlikely. To the best of our knowledge, all of such species that have been characterized possess $14 \mathrm{ME}$. In the case of $\mathrm{RbNb}_{6} \mathrm{Cl}_{12} \mathrm{O}_{2}$, the substitution of two inner chlorides by oxygen atoms does not lead to a strong destabilization of the band that derives from the $a_{2 u}$ level. From a theoretical point of view, the overall non-bonding behaviour of this $a_{2 u}$ band results in an optimal $\mathrm{ME}$ count of 16 for $\mathrm{Nb}_{6} \mathrm{Cl}_{10}^{\mathrm{i}} \mathrm{O}_{2}^{\mathrm{i}}$ clusters in this compound. However, attempts to reduce these 14- and 15-EM compounds have been unsuccessful so far.

Results obtained before on molecular $\mathrm{Nb}_{6} \mathrm{Cl}_{15} \mathrm{O}_{3}$ clusters ${ }^{40}$ suggest that the electronic structure of $\mathrm{Na}_{0.21} \mathrm{Nb}_{6} \mathrm{Cl}_{10.5} \mathrm{O}_{3}$ which is also built up from the trans $-\mathrm{Nb}_{6} \mathrm{Cl}_{9}^{\mathrm{i}} \mathrm{O}_{3}^{\mathrm{i}}$ cluster core should be characterized by a high-lying $a_{2 u}$ band. DOS and COHP curves computed for the model compound $\mathrm{Na}_{0.5} \mathrm{Nb}_{6}$ $\mathrm{Cl}_{10.5} \mathrm{O}_{3}$ as shown in Fig. 4 confirm this hypothesis. The $\mathrm{ME}$ count of the $\mathrm{Nb}_{6}$ cluster in $\mathrm{Na}_{0.5} \mathrm{Nb}_{6} \mathrm{Cl}_{10.5} \mathrm{O}_{3}$ is equal to 14; the $a_{2 u}$ band that lies one $\mathrm{eV}$ above the Fermi level is vacant. As shown by COHP curves, no appreciable interaction occurs between clusters. Integrated COHP of intercluster $\mathrm{Nb}-\mathrm{Nb}$ contacts is more than 50 times smaller than the averaged one for intra- $\mathrm{Nb}_{6}$ metal-metal contacts. Small width of the DOS peaks also demonstrates the 0 -D character of this compound. Averaged intracluster $\mathrm{Nb}-\mathrm{Nb}$ distances in $\mathrm{Na}_{0.21} \mathrm{Nb}_{6} \mathrm{Cl}_{10.5} \mathrm{O}_{3}$ are longer than those in $\mathrm{Rb}_{0.816} \mathrm{Nb}_{6} \mathrm{Cl}_{12} \mathrm{O}_{2}$, $2.961 \AA$ vs. $2.939 \AA$, respectively. Two electronic effects can be at the origin of this difference. Firstly, the $a_{2 u}$ band that shows $\mathrm{Nb}-\mathrm{Nb}$ bonding character is vacant in the sodium compound. Secondly, the experimental ME count of the $\mathrm{Nb}_{6}$ cluster is equal to 13.71. Assuming a rigid band model, this electron count leads to some depopulation of the top of the valence band that is mainly $\mathrm{Nb}-\mathrm{Nb}$ bonding. On the basis of these results, it is obvious that the optimal ME count of such a unit is 14. If this ME count could be reached experimentally, the resulting compound should behave as a diamagnetic semiconductor.

In 1999, Lachgar et al. reported the synthesis and the crystal structure of $\mathrm{Ti}_{2} \mathrm{Nb}_{6} \mathrm{O}_{12}$ as well as its theoretical study on the basis of EH-TB calculations. ${ }^{31}$ Some years later, its electronic structure was revisited using DFT calculations as well as that of $\mathrm{Na}_{2}\left(\mathrm{Sc}_{4} \mathrm{Nb}_{2}\right)\left(\mathrm{Nb}_{6} \mathrm{O}_{12}\right)_{3} \cdot{ }^{32}$ The electronic structures of both 


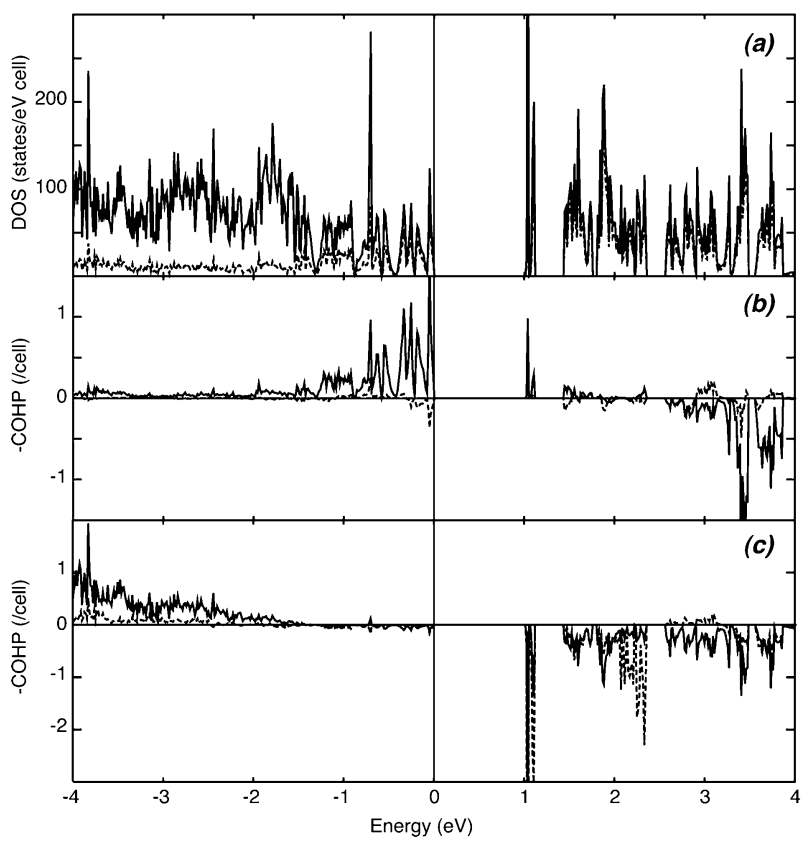

Fig. 4 LMTO calculations for $\mathrm{Na}_{0.5} \mathrm{Nb}_{6} \mathrm{Cl}_{10.5} \mathrm{O}_{3}$ : (a) total DOS (solid) and $\mathrm{Nb}$ contribution (dotted), (b) intracluster $\mathrm{Nb}-\mathrm{Nb}$ ranging from $2.781 \AA$ to $3.036 \AA$ (solid) and intercluster $\mathrm{Nb}-\mathrm{Nb}(3.396 \AA$, dotted) COHP curves, (c) $\mathrm{Nb}-\mathrm{O}^{\mathrm{i}}$ ranging from $1.967 \AA$ to $1.980 \AA$ (solid) and $\mathrm{Nb}-\mathrm{Cl}^{\mathrm{i}}$ ranging from $2.439 \AA$ to $2.515 \AA$ (dotted) $\mathrm{COHP}$ curves.

compounds present a band gap of less than half an $\mathrm{eV}$, which separates occupied bands from vacant bands. In both cases, the $a_{2 u}$ band overlaps with the d orbital of additional transition metals of the crystal structure: $\mathrm{Ti}$ in $\mathrm{Ti}_{2} \mathrm{Nb}_{6} \mathrm{O}_{12}, \mathrm{Sc}$ and $\mathrm{Nb}$ in $\mathrm{Na}_{2}\left(\mathrm{Sc}_{4} \mathrm{Nb}_{2}\right)\left(\mathrm{Nb}_{6} \mathrm{O}_{12}\right)_{3} \cdot{ }^{32}$ Although the presence of oxygen ligands around niobium atoms of the octahedral cluster leads to a decrease of intercluster $\mathrm{Nb}-\mathrm{Nb}$ contacts equal to $3.315 \AA$ in the titanium compound and to $3.213 \AA$ in $\mathrm{Na}_{2}\left(\mathrm{Sc}_{4} \mathrm{Nb}_{2}\right)\left(\mathrm{Nb}_{6} \mathrm{O}_{12}\right)_{3}$, with respect to non-oxygenated species, $\mathrm{Nb}-\mathrm{Nb}$ interactions between clusters are negligible. This is supported by the very small ICOHP values computed for these contacts that are two orders of magnitude smaller than the one calculated for $\mathrm{Nb}-\mathrm{Nb}$ bonds within the cluster. On the basis of the EH-TB electronic structure, Lachgar et al. expected that interesting properties can be foreseen if a one-electron reduction of $\mathrm{Ti}_{2} \mathrm{Nb}_{6} \mathrm{O}_{12}$ could be achieved. ${ }^{31}$ Our previous study showed that the strong metal-oxygen antibonding character of the lowest bands of the conduction band makes unfavourable such a reduction. ${ }^{32}$

Therefore, the replacement of inner halogen by oxygen ligands does not favour strong electronic interactions between the neighbouring edge-bridged $\mathrm{Nb}_{6} \mathrm{~L}_{12}^{\mathrm{i}} \mathrm{L}_{6}^{\mathrm{a}}$ units through double $\mathrm{O}^{\mathrm{i}-\mathrm{a}} / \mathrm{O}^{\mathrm{a}-\mathrm{i}}$ as those previously observed in Chevrel phases wherein face-capped $\mathrm{Mo}_{6} \mathrm{Y}_{8}^{\mathrm{i}} \mathrm{Y}_{6}^{\mathrm{a}}$ units are condensed by double $\mathrm{Y}^{\mathrm{i}-\mathrm{a}} / \mathrm{Y}^{\mathrm{a}-\mathrm{i}}$ bridges $(\mathrm{Y}=\mathrm{S}, \mathrm{Se}$ and $\mathrm{Te})$. Niobium oxides are characterized by a strong molecular character. Although the $a_{2 u}$ band of their electronic structures has the same d-type orientation with respect to the p-orbitals of the outer ligands than the $e_{g}$ band of molybdenum chalcogenides, Anokhina et al. proposed that it could be due to a weaker hybridization with low lying bands. ${ }^{39}$

\section{Magnetic properties of $\mathrm{A}_{x} \mathrm{Nb}_{6} \mathrm{Cl}_{12} \mathrm{O}_{2}$ compounds $(\mathrm{A}=\mathrm{Rb}, \mathrm{Cs})$}

The magnetic susceptibility measurements carried out on $\mathrm{A}_{x} \mathrm{Nb}_{6} \mathrm{Cl}_{12} \mathrm{O}_{2}(\mathrm{~A}=\mathrm{Cs}, x=1 ; \mathrm{A}=\mathrm{Rb}, x=0.816(8))$ that contains some 15-ME species are shown in Fig. 5a and b, respectively. The effective moment deduced earlier from these measurements, calculated above $50 \mathrm{~K}$ according to the usual Curie-Weiss law, is $\mu_{\mathrm{eff}}=1.42 \mu_{\mathrm{B}}$ for $\mathrm{CsNb}_{6} \mathrm{Cl}_{12} \mathrm{O}_{2}$ and $\mu_{\text {eff }}=1.37 \mu_{\mathrm{B}}$ for $\mathrm{Rb}_{0.816} \mathrm{Nb}_{6} \mathrm{Cl}_{12} \mathrm{O}_{2} .{ }^{27}$ However, as seen from Fig. 5, the magnetic susceptibility for both compounds shows some deviation from the hyperbolic behaviour typical for the Curie or Curie-Weiss law, with a tendency of forming
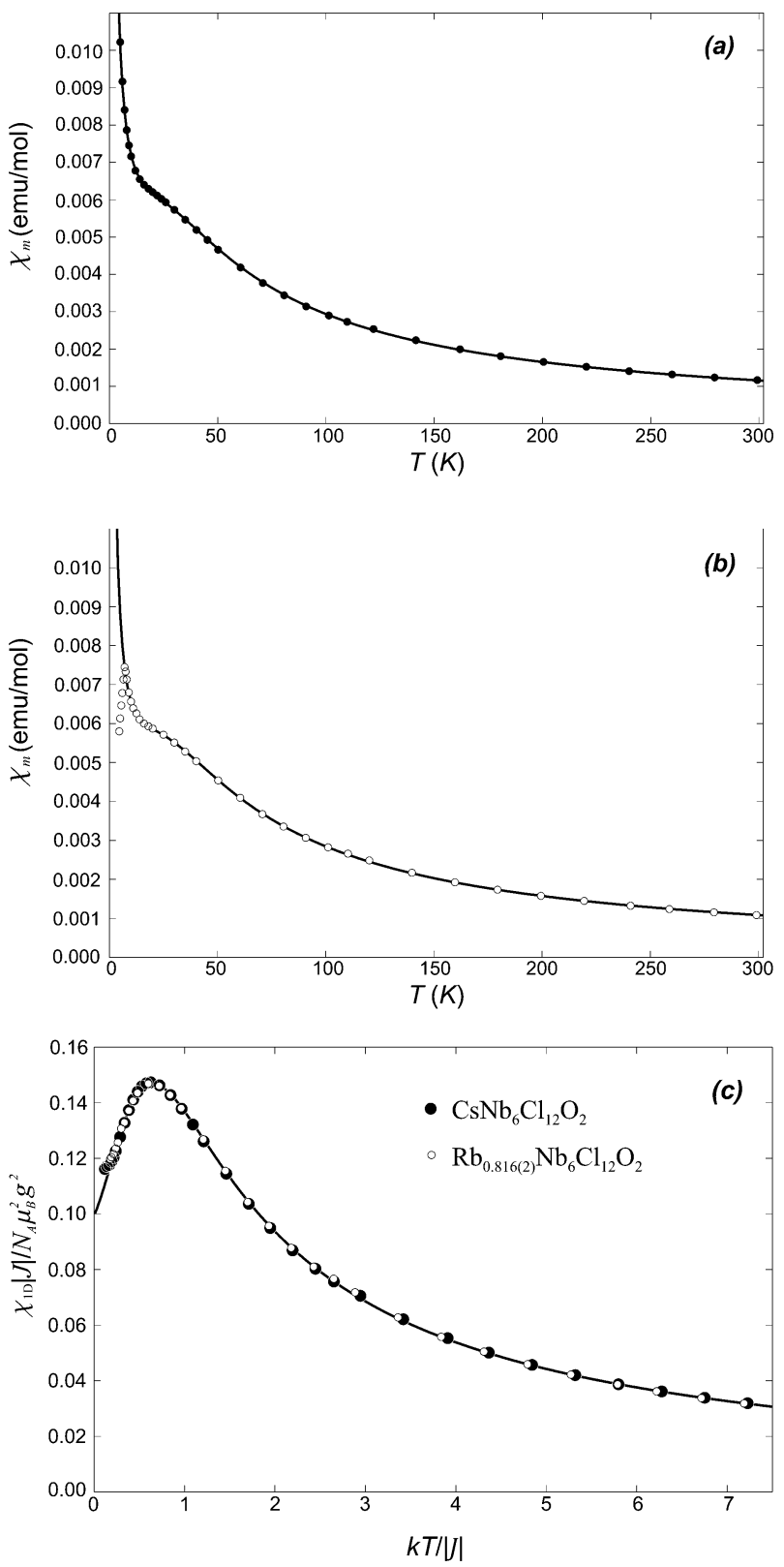

Fig. 5 Temperature dependent magnetic susceptibility $\chi_{\mathrm{m}}$ of (a) $\mathrm{CsNb}_{6} \mathrm{Cl}_{12} \mathrm{O}_{2}$ and (b) $\mathrm{Rb}_{0.816(8)} \mathrm{Nb}_{6} \mathrm{Cl}_{12} \mathrm{O}_{2}$. Solid curves represent the best fits to the $\mathrm{CsNb}_{6} \mathrm{Cl}_{12} \mathrm{O}_{2}$ and $\mathrm{Rb}_{0.816(8)} \mathrm{Nb}_{6} \mathrm{Cl}_{12} \mathrm{O}_{2}$ data, respectively. (c) The $\chi_{1 \mathrm{D}}$ contribution to $\chi_{\mathrm{m}}$ shown as the normalized susceptibility $\chi_{1 \mathrm{D}}|J| / N_{\mathrm{A}} g^{2} \mu_{\mathrm{B}}{ }^{2} v s . k T /|J|$. Solid curve represents the 1-D Bonner-Fisher susceptibility model. 
more flat temperature dependence in the region of $20-30 \mathrm{~K}$. A similar magnetic behaviour was further encountered for $\mathrm{In}_{0.63} \mathrm{Nb}_{6} \mathrm{Cl}_{12} \mathrm{O}_{2}{ }^{39}$ This encouraged us to study more accurately the magnetic properties of $\mathrm{CsNb}_{6} \mathrm{Cl}_{12} \mathrm{O}_{2}$ in which all clusters have a single unpaired electron as well as those of $\mathrm{Rb}_{0.816} \mathrm{Nb}_{6} \mathrm{Cl}_{12} \mathrm{O}_{2}$ where the $\mathrm{Rb}$ site is not fully occupied. The purity of the two compounds was checked by the X-ray powder diffraction: the Cs compound pattern does not evidence any secondary phases while the $\mathrm{Rb}$ one evidences few traces of metallic $\mathrm{Nb}$. As a consequence the magnetic analysis was performed on the whole temperature range for the Cs compound and only above $10 \mathrm{~K}$ for the $\mathrm{Rb}$ one.

Magnetic susceptibility is supposed to consist of three main parts:

$$
\chi_{\mathrm{m}}=\chi_{\text {ind }}+p \chi_{\text {Curie }}+(1-p) \chi_{1 D}
$$

$\chi_{1 \mathrm{D}}$ is the 1-D Bonner-Fisher model for a chain of interacting paramagnetic centers: ${ }^{43,44}$

$$
\chi_{1 \mathrm{D}}=\frac{N_{\mathrm{A}} g^{2} \mu_{\mathrm{B}}^{2}}{k T} \frac{0.25+0.074975 x+0.075235 x^{2}}{1.0+0.9931 x+0.172135 x^{2}+0.757825 x^{3}}
$$

where $N_{\mathrm{A}}, \mu_{\mathrm{B}}$ and $k$ are the Avogadro number, the Bohr magneton and the Boltzmann constant, respectively; $g$ is the $g$-factor of the paramagnetic cluster and $x=|J| / k T$ where $J$ is the exchange coupling constant (magnetic interaction parameter). $J$ takes place in the Heisenberg Hamiltonian which defines the magnetic interaction of unpaired spins in the pair of nearest neighbouring cluster units: $\hat{H}=-J \boldsymbol{S}_{i} \boldsymbol{S}_{j} \cdot \chi_{\text {Curie }}$ in eqn (1) is the Curie law for spin $S=1 / 2$ :

$$
\chi_{\text {Curie }}=\frac{N_{\mathrm{A}} g^{2} \mu_{\mathrm{B}}^{2}}{4 k T}
$$

$g$-values in eqn (2) and (3) are taken to be 1.951, according to electron paramagnetic resonance data. ${ }^{25,27}$ In eqn (1) it is supposed that only a molar fraction $p$ of paramagnetic clusters contributes to the Curie law, coming from clusters located at the defects of the crystal structure. The rest of the fraction $(1-p)$ comes from the 1-D chains represented in Fig. 2a. Existence of these structural 1-D chains of paramagnetic $\mathrm{Nb}_{6} \mathrm{Cl}_{14} \mathrm{O}_{4}$ clusters in $\mathrm{CsNb}_{6} \mathrm{Cl}_{12} \mathrm{O}_{2}$ and $\mathrm{Rb}_{0.816} \mathrm{Nb}_{6} \mathrm{Cl}_{12} \mathrm{O}_{2}$ is the main reason for consideration of the 1-D Bonner-Fisher model in this analysis of the magnetic susceptibility data. For the $\mathrm{Rb}$ compound, the temperature dependence coming from the paramagnetic phase of metallic niobium in the sample was not taken into account. It is known that the susceptibility change for pure niobium in the temperature region between 10 and $300 \mathrm{~K}$ is only $3 \%$ of its absolute value ${ }^{45}$ which is again suppressed by much smaller molar contribution of this kind of impurity in the sample. Nevertheless, we assume that deviation of the first few data points measured at the lowest temperatures (Fig. 5b) originates from the phase transition of niobium impurities into the superconducting phase.

$\chi_{\text {ind }}$ in eqn (1) is supposed to consist of three main temperature independent parts: ${ }^{46}$

$$
\chi_{\text {ind }}=\chi_{\text {Pascal }}+\chi_{\text {deloc }}+\chi_{\text {TIP }}
$$

$\chi_{\text {Pascal }}$ is the atomic diamagnetic contribution summed over all constituents of the compounds. $\chi_{\text {deloc }}$ is the diamagnetic correction coming from the 15 delocalized ME of the cluster. ${ }^{46}$ $\chi_{\text {TIP }}$ is the temperature independent paramagnetism of a cluster unit. Experimental data for $\mathrm{Rb}_{0.816(8)} \mathrm{Nb}_{6} \mathrm{Cl}_{12} \mathrm{O}_{2}$ $(T>10 \mathrm{~K})$ and $\mathrm{CsNb}_{6} \mathrm{Cl}_{12} \mathrm{O}_{2}$ were fitted on the model given in eqn (1) by a non-linear fit procedure of the MATLAB software. ${ }^{47}$ The best fitted parameters for $\mathrm{CsNb}_{6} \mathrm{Cl}_{12} \mathrm{O}_{2}$ are: $|J|=28.7(2) \mathrm{cm}^{-1}, p=0.0914(6)$ and $\chi_{\text {ind }}=5(2) \times 10^{-6} \mathrm{emu}$ $\mathrm{mol}^{-1}$, while for $\mathrm{Rb}_{0.816(8)} \mathrm{Nb}_{6} \mathrm{Cl}_{12} \mathrm{O}_{2}$ these parameters are: $|J|=28.9(2) \mathrm{cm}^{-1}, p=0.0741(9)$ and $\chi_{\text {ind }}=-1.7(7) \times$ $10^{-6} \mathrm{emu} \mathrm{mol}^{-1}$. The solid curves in Fig. 5a and b are theoretical curves based on eqn (1) and the best fitting parameters for $\mathrm{CsNb}_{6} \mathrm{Cl}_{12} \mathrm{O}_{2}$ and $\mathrm{Rb}_{0.816} \mathrm{Nb}_{6} \mathrm{Cl}_{12} \mathrm{O}_{2}$, respectively. The small values of the discrepancy factor $R\left(R=\Sigma\left(\chi_{\mathrm{m}}-\chi_{\text {calc }}\right)^{2} / \Sigma\left(\chi_{\mathrm{m}}\right)^{2}\right)$ that is equal to $5.938 \times 10^{-5}$ and $9.838 \times 10^{-6}$ for the $\mathrm{Cs}$ and $\mathrm{Rb}$ compounds, respectively, show the good quality of the fits. The values for the magnetic interaction parameter $|J|$ are almost identical for both compounds. The $\chi_{\text {ind }}$ value obtained for $\mathrm{CsNb}_{6} \mathrm{Cl}_{12} \mathrm{O}_{2}$, using a value of $-373 \times 10^{-6} \mathrm{emu} \mathrm{mol}^{-1}$ for $\chi_{\text {Pascal }}$ and estimation of $-178 \times 10^{-6} \mathrm{emu} \mathrm{mol}^{-1}$ for $\chi_{\text {deloc }}(15 \mathrm{ME}$ that move around the cluster approximated by the sphere of radius $2.05 \times$ $\left.10^{-10} \mathrm{~m}\right),{ }^{46}$ gives the value of $556(2) \times 10^{-6} \mathrm{emu} \mathrm{mol}^{-1}$ for $\chi_{\text {TIP }}$ of cluster $\mathrm{Nb}_{6} \mathrm{Cl}_{14} \mathrm{O}_{4}$. This value is in accordance with analogous estimations of $\chi_{\text {TIP }}$ of various $\mathrm{Nb}_{6}$ or $\mathrm{Ta}_{6}$ clusters as determined by Converse and McCarley, ${ }^{46}$ supporting further the magnetic susceptibility model used in the present analysis. For $\mathrm{Rb}_{0.816(8)} \mathrm{Nb}_{6} \mathrm{Cl}_{12} \mathrm{O}_{2}$, such a determination of $\chi_{\text {TIP }}$ is not reliable, because of the deficiency of $\mathrm{Rb}$ cations in the structure and the presence of additional niobium impurities. Requirement of the total charge neutrality for whole compound reveals some percentage of the diamagnetic $\mathrm{Nb}_{6} \mathrm{Cl}_{14} \mathrm{O}_{4}$ clusters (14 ME) contributing to the measured $\chi_{\text {ind }}$ and rendering eqn (4) incorrect.

To examine in more detail the one-dimensional character of the magnetic susceptibility model, for every measured data $\left(\chi_{\mathrm{m}}, T\right)$ the contribution of the 1-D Bonner-Fisher model $\chi_{1 \mathrm{D}}$ was calculated using eqn (1) and $\chi_{\text {ind }}$ and $p$ values were obtained from the fits. Curie contribution $\chi_{\text {Curie }}$ was calculated from eqn (3). Corrected magnetic susceptibilities are represented in Fig. $5 \mathrm{c}$ as reduced susceptibility $\chi_{1 \mathrm{D}}|J| / N_{\mathrm{A}} g^{2} \mu_{\mathrm{B}}{ }^{2} v s$. $k T /|J|$ (for $\mathrm{Rb}_{0.816(8)} \mathrm{Nb}_{6} \mathrm{Cl}_{12} \mathrm{O}_{2}$ data above $10 \mathrm{~K}$ are shown). The solid curve represents the theoretical Bonner-Fisher susceptibility model. Experimental data follow this model very accurately. Very slight distortion at lower temperatures may arise from using the infinite 1-D chain model, while for finite chains with an odd number of paramagnetic centres, as well as for averages of the chains with odd and even numbers of paramagnetic centres, the theory predicts the increase of magnetic susceptibility at lower temperatures. ${ }^{43,44}$ Taking into account this information, the values for $p$ obtained in the present analysis could be overestimated.

Existence of the intercluster magnetic interaction is also confirmed theoretically. Indeed, the value of the magnetic interaction parameter was computed using a spin-dimer analysis. ${ }^{48}$ Such an approach has been recently used to elucidate the magnetic interactions in some related compounds that contain 15- $\mathrm{ME} \mathrm{Nb}_{6}$ and $\mathrm{Ta}_{6}$ cluster units. ${ }^{49,50}$ Wave-function-methods 
provide an accurate description after an important computational effort. The broken symmetry (BS) approach combined with DFT is an alternative computational tool that has been successfully applied to study magnetic interactions in numerous compounds. ${ }^{51}$ In this approach, the magnetic coupling constant can be written as

$$
J=2\left(E_{\mathrm{BS}}-E_{\mathrm{T}}{ }^{\prime}\right) /\left(1+S^{2}\right)
$$

where $E_{\mathrm{T}}{ }^{\prime}$ and $E_{\mathrm{BS}}$ are the energies of the unrestricted triplet spin state and BS solution, respectively, and $S$ is the overlap integral between magnetic orbitals of the BS solution. ${ }^{51}$

From the X-ray crystal structures of $\mathrm{CsNb}_{6} \mathrm{Cl}_{12} \mathrm{O}_{2}$, the $\mathrm{Nb}_{12} \mathrm{Cl}_{20}^{\mathrm{i}} \mathrm{O}_{2}^{\mathrm{i}} \mathrm{O}^{\mathrm{i}-\mathrm{a}} \mathrm{Cl}_{8}^{\mathrm{a}} \mathrm{O}_{2}^{\mathrm{a}} \mathrm{O}^{\mathrm{a}-\mathrm{i}}$ dimer has been computed in the $\mathrm{BS}$ and $\mathrm{T}^{\prime}$ spin states. The BS spin state is more stable than the $\mathrm{T}^{\prime}$ state; $\left(E_{\mathrm{BS}}-E_{\mathrm{T}}{ }^{\prime}\right)$ is equal to $-0.0034 \mathrm{eV}$. As previously shown on the basis of EH calculations, ${ }^{39}$ the strong localised limit $S=0$ can be assumed. The $J$ value is then estimated to be $-54 \mathrm{~cm}^{-1}$, which is of the same order of magnitude than the experimental values fitted close to $-29 \mathrm{~cm}^{-1}$. These calculations support the experimental determinations based on fittings from magnetic susceptibility measurements. Indeed, the conclusion is that even if no strong interactions occur between clusters (as suggested by periodic DFT calculations), a weak antiferromagnetic coupling arises from small but significant interactions of the $a_{2 u}$ molecular orbitals of neighbouring clusters which generate a flat band at the Fermi level.

\section{Conclusions}

The electronic structures of oxides and oxyhalides $\mathrm{Nb}_{6}$ cluster compounds interconnected by $\mathrm{O}^{\mathrm{i}-\mathrm{a}} / \mathrm{O}^{\mathrm{a}-\mathrm{i}}$ bridges strongly depend on those of the $\mathrm{Nb}_{6} \mathrm{Cl}_{12-x}^{\mathrm{i}} \mathrm{O}_{x}^{\mathrm{i}} \mathrm{Cl}_{6-y}^{\mathrm{a}} \mathrm{O}_{y}^{\mathrm{a}}$ unit. The increasing number $x$ of oxygens in the octahedral cluster unit reinforces the $\mathrm{Nb}-\mathrm{L}^{\mathrm{i}}$ antibonding character of the $a_{2 u}$ band in the vicinity of the Fermi level and makes its occupation unlikely, leading to the favoured ME count of 14 per $\mathrm{Nb}_{6}$ unit. Periodic DFT calculations show that very weak interactions occur between the neighbouring clusters. This differs from Chevrel phases where strong intercluster interactions occur between face-capped octahedral $\mathrm{Mo}_{6}$ clusters interconnected via similar bridges. However, $15 \mathrm{ME}-\mathrm{Nb}_{6}$ neighbouring clusters of chains containing $\mathrm{A}_{x} \mathrm{Nb}_{6} \mathrm{Cl}_{12} \mathrm{O}_{2}$ compounds weakly couple antiferromagnetically at low temperatures as shown by susceptibility measurements and BS-DFT calculations.

\section{Experimental section}

\section{Computational details}

Self-consistent $a b$ initio band structure calculations were performed on $\mathrm{Rb}_{0.816} \mathrm{Nb}_{6} \mathrm{Cl}_{12} \mathrm{O}_{2}$ and $\mathrm{Na}_{0.21} \mathrm{Nb}_{6} \mathrm{Cl}_{10.5} \mathrm{O}_{3}$ with the scalar relativistic tight-binding linear muffin-tin orbital (LMTO) method in the atomic spheres approximation including the combined correction. ${ }^{52}$ Because of the fractional occupation of the $\mathrm{Rb}$ and $\mathrm{Na}$ positions, $\mathrm{RbNb}_{6} \mathrm{Cl}_{12} \mathrm{O}_{2}$ and $\mathrm{Na}_{0.5} \mathrm{Nb}_{6} \mathrm{Cl}_{10.5} \mathrm{O}_{3}$ model compounds were considered. Exchange and correlation were treated in the local density approximation using the von Barth-Hedin local exchange-correlation potential. ${ }^{53}$ Within the LMTO formalism, interatomic spaces were filled with interstitial spheres. The optimal positions and radii of these additional "empty spheres" (ES) were determined by the procedure described in ref. 54. Twenty-two and sixteen nonsymmetry-related ES with $0.72 \leq r_{\mathrm{ES}} \leq 1.85 \AA$ and $0.72 \leq r_{\mathrm{ES}} \leq 2.41 \AA$ were introduced for the calculations of $\mathrm{RbNb}_{6} \mathrm{Cl}_{12} \mathrm{O}_{2}$ and $\mathrm{Na}_{0.5} \mathrm{Nb}_{6} \mathrm{Cl}_{10.5} \mathrm{O}_{3}$, respectively. The full LMTO basis set consisted of $5 \mathrm{~s}, 5 \mathrm{p}, 4 \mathrm{~d}$ and $4 \mathrm{f}$ functions for $\mathrm{Nb}$ spheres, 5s, 5p, 4d and 4f functions for Rb spheres, 4s, 3p, $3 \mathrm{~d}$ and $4 \mathrm{f}$ functions for $\mathrm{Cl}$ spheres, $3 \mathrm{~s}, 2 \mathrm{p}, 3 \mathrm{~d}$ and $4 \mathrm{f}$ functions for $\mathrm{O}$ spheres, $3 \mathrm{~s}, 3 \mathrm{p}$ and $3 \mathrm{~d}$ functions for $\mathrm{Na}$ spheres and $\mathrm{s}, \mathrm{p}$ and $\mathrm{d}$ functions for ES. The eigenvalue problem was solved using the following minimal basis set obtained from the Löwdin down-folding technique: $\mathrm{Nb} 5 \mathrm{~s}, 5 \mathrm{p}$ and $4 \mathrm{~d} ; \mathrm{Rb} 5 \mathrm{~s}$; $\mathrm{Cl} 3 \mathrm{p}$; O 2p; Na 3s; and interstitial 1s LMTOs. The $k$-space integration was performed using the tetrahedron method. ${ }^{55}$ Charge self-consistency and average properties were obtained from 152 and 36 irreducible $k$-points for the calculations of $\mathrm{RbNb}_{6} \mathrm{Cl}_{12} \mathrm{O}_{2}$ and $\mathrm{Na}_{0.5} \mathrm{Nb}_{6} \mathrm{Cl}_{10.5} \mathrm{O}_{3}$, respectively. A measure of the magnitude of the bonding was obtained by computing the crystal orbital Hamiltonian populations (COHP), which are the Hamiltonian population weighted density of states (DOS). ${ }^{56}$ As recommended, a reduced basis set (in which all ES LMTO's were downfolded) was used for the COHP calculations. ${ }^{57}$ Bands, DOS and COHP curves were shifted so that the Fermi level lies at $0 \mathrm{eV}$.

Magnetic interaction parameters were computed using Amsterdam Density Functional (ADF) package, version $2009{ }^{58}$ PBE non-local gradient corrections ${ }^{59}$ were included in the local density approximation. ${ }^{60} \mathrm{~A}$ TZP basis set in ADF was taken, containing triple- $\zeta$ basis sets for all atoms present in our models and a polarisation function for $\mathrm{Nb}, \mathrm{Cl}$, and $\mathrm{O}$ atoms. A frozen-core approximation was used to treat the core electrons of $\mathrm{Nb}(1 \mathrm{~s}-3 \mathrm{~d}), \mathrm{Cl}(1 \mathrm{~s}-2 \mathrm{p})$, and $\mathrm{O}(1 \mathrm{~s}) .{ }^{61}$ Scalar relativistic calculations using the zero-order regular approximation (ZORA) were performed. ${ }^{62}$ The energy convergence criterion was smaller than $10^{-6} \mathrm{eV}$, allowing us to reach the precision required for the evaluation of the $J$ values.

\section{Magnetic measurements}

The susceptibility data were measured on powder samples using a Quantum Design SQUID magnetometer between 4 and $300 \mathrm{~K}$ at an applied field of $1 \mathrm{kG}$. The susceptibility follows a Curie-Weiss behaviour above $50 \mathrm{~K}$, with a curvature away from linearity in the reciprocal susceptibility plot at low temperature.

\section{Acknowledgements}

This work was made in the framework of the French-Croatian PHC COGITO program (2009-2010/19646UJ). BP and RG gratefully acknowledge CNRS for an invited research associate position to BP. The French GENCI (Grand Equipement National de Calcul Intensif) centre is acknowledged for high performance computing resources of CINES (Grant 2010-86170).

\section{Notes and references}

1 F. A. Cotton, Inorg. Chem., 1964, 3, 1217.

2 H. Schäfer and H. G. Schnering, Angew. Chem., 1964, 76, 833. 
3 G. Prabusankar, Y. Molard, S. Cordier, S. Golhen, Y. Le Gal, C. Perrin, S. Kalal, J. F. Halet and L. Ouahab, Eur. J. Inorg. Chem., 2009, 2153.

4 D. Mery, L. Plault, C. Ornelas, J. Ruiz, S. Nlate, D. Astruc, J. C. Blais, J. Rodrigues, S. Cordier, K. Kirakci and C. Perrin, Inorg. Chem., 2006, 45, 1156.

5 S. Cordier, K. Kirakci, D. Méry, C. Perrin and D. Astruc, Inorg. Chim. Acta, 2006, 359, 1705.

6 D. Méry, C. Ornelas, M.-C. Daniel, J. Ruiz, J. Rodrigues, D. Astruc, S. Cordier, K. Kirakci and C. Perrin, C. R. Chim., 2005, 8, 1789 .

7 F. Grasset, Y. Molard, S. Cordier, F. Dorson, M. Mortier, C. Perrin, M. Guilloux-Viry, T. Sasaki and H. Haneda, Adv. Mater., 2008, 20, 1710.

8 T. Aubert, F. Grasset, S. Mornet, E. Duguet, O. Cador, S. Cordier, Y. Molard, V. Demange, M. Mortier and H. Haneda, J. Colloid Interface Sci., 2010, 341, 201.

9 Y. Molard, F. Dorson, V. Circu, T. Roisnel, F. Artzner and S. Cordier, Angew. Chem., Int. Ed., 2010, 49, 3351.

10 A. S. Mocanu, M. Amela-Cortes, Y. Molard, V. Circu and S. Cordier, Chem. Commun., 2011, 47, 2056.

11 N. Naumov, S. Cordier and C. Perrin, Solid State Sci., 2005, 7, 1517.

12 N. Naumov, S. Cordier and C. Perrin, Solid State Sci., 2003, 5, 1359.

13 J. J. Zhang and A. Lachgar, J. Am. Chem. Soc., 2007, 129, 250.

14 S. Ababou-Girard, S. Cordier, B. Fabre, Y. Molard and C. Perrin, ChemPhysChem, 2007, 8, 2086.

15 B. Fabre, S. Cordier, Y. Molard, C. Perrin, S. Ababou-Girard and C. Godet, J. Phys. Chem. C, 2009, 113, 17437.

16 S. Cordier, O. Hernandez and C. Perrin, J. Solid State Chem., 2002, 163, 319-324.

17 B. Bajan and H.-J. Meyer, Z. Anorg. Allg. Chem., 1997, 623, 791.

18 H. Schäfer, H. G. Schnering, K.-J. Niehues and H. G. NiederVahrenholz, J. Less Common Met., 1965, 9, 95.

19 S. Cordier and A. Simon, Solid State Sci., 1999, 1, 199.

20 S. Cordier, O. Hernandez and C. Perrin, J. Solid State Chem., 2001, 158, 327.

21 A. Simon, H. G. Schnering, H. Wöhrle and H. Schäfer, Z. Anorg. Allg. Chem., 1965, 339, 155.

22 (a) R. Knoll, J. Sokolovski, Y. BenHaim, A. I. Shames, S. D. Goren, H. Shaked, J.-Y. Thépot, C. Perrin and S. Cordier, Physica B (Amsterdam), 2006, 381, 47; (b) W. A. MacFarlane, D. Schick-Martin, M. Egilmez, I. Fanc, Q. Song, K. H. Chow, S. Cordier, C. Perrin and S. D. Goren, Physica B (Amsterdam), 2009, 404, 622.

23 S. Ihmaine, C. Perrin, O. Peña and M. Sergent, J. Less Common Met., 1988, 137, 323

24 S. Cordier, F. Gulo, T. Roisnel, R. Gautier, B. Le Guennic, J.-F. Halet and C. Perrin, Inorg. Chem., 2003, 42, 8320.

25 F. Gulo and C. Perrin, J. Mater. Chem., 2000, 10, 1721.

26 S. Cordier, C. Perrin and M. Sergent, Eur. J. Solid State Inorg. Chem., 1994, 31, 1049.

27 F. Gulo, Ph.D. Thesis, University of Rennes 1, 2001.

28 Crystal data for $\mathrm{Rb}_{0.816(8)} \mathrm{Nb}_{6} \mathrm{Cl}_{12} \mathrm{O}_{2}$ : sample size $=0.05 \times 0.04 \times$ $0.03 \mathrm{~mm}^{3}$, monoclinic system, space group $P 2_{1} / c, a=6.8097(4) \AA$, $b=11.6699(9) \AA, c=12.5090(9) \AA, \beta=101.337(4)^{\circ}$, $V=974.7(1) \AA^{3}, Z=2, M_{\mathrm{r}}=1084.61 \mathrm{~g} \mathrm{~mol}^{-1}, \rho_{\text {calcd }}=$ $3.695 \mathrm{~g} \mathrm{~cm}^{3}, \lambda=0.71069 \AA$ A $\left(\right.$ Mo $\left.K_{\alpha}\right)$, Enraf Nonius KappaCCD diffractometer, $T=293 \mathrm{~K}, \theta_{\max }=35^{\circ}, 13468$ reflections, 4223 independent reflections $\left(R_{\mathrm{int}}=0.1178\right), 101$ parameters, 0 constraint, full-matrix least-squares refinement on $F^{2}$ (SHELXL Program $^{29}$ ), $R_{1}=0.059, \mathrm{w} R_{2}=0.090, S=1.052$, largest difference peak and hole +1.94 and $-2.81{\mathrm{e} \AA^{-3} \text {. Structure }}_{29}$ solution solved by direct methods using SHELXS Program. ${ }^{29}$ Further details of the crystal structure investigation may be obtained from the authors.

29 G. M. Sheldrick, SHELX97-Programs for Crystal Structure Analysis (Release 97-2), Institüt für Anorganische Chemie der Universität, Tammanstrasse 4, D-3400 Göttingen, Germany, 1998.

30 F. Gulo and C. Perrin, J. Solid State Chem., 2002, 163, 325.

31 E. V. Anokhina, M. W. Essig, C. S. Day and A. Lachgar, J. Am. Chem. Soc., 1999, 121, 6827.

32 S. Cordier, K. Kirakci, B. Fontaine, J.-F. Halet, R. Gautier and C. Perrin, Inorg. Chem., 2006, 45, 883.
$33 \mathrm{CsNb}_{6} \mathrm{Cl}_{12} \mathrm{O}_{2}{ }^{25}$ is built up from $\mathrm{Nb}_{6} \mathrm{Cl}_{10}^{\mathrm{i}} \mathrm{O}_{2}^{\mathrm{i}} \mathrm{Cl}_{4}^{\mathrm{a}} \mathrm{O}_{2}^{\mathrm{a}}$ units (2 inner oxygen and 2 apical oxygen among the 18 ligands). Double $\mathrm{O}^{\mathrm{i}-\mathrm{a}} /$ $\mathrm{O}^{\mathrm{a}-1}$ bridges interconnect $\mathrm{Nb}_{6}$ octahedra to form $\mathrm{Nb}_{6} \mathrm{Cl}_{10}^{\mathrm{i}} \mathrm{O}_{2 / 2}^{\mathrm{i}-\mathrm{a}} \mathrm{Cl}_{4}^{\mathrm{a}} \mathrm{O}$ ${ }_{2 / 2}^{a-i}$ infinite chains. These chains are linked by the 4 remaining chlorine atoms to form a $\mathrm{Nb}_{6} \mathrm{Cl}_{10}^{\mathrm{i}} \mathrm{O}_{2 / 2}^{\mathrm{i}-\mathrm{a}} \mathrm{Cl}_{4 / 2}^{\mathrm{a}-\mathrm{a}} \mathrm{O}_{2 / 2}^{\mathrm{a}-\mathrm{i}}$ 3-D framework. The $\mathrm{A}_{x} \mathrm{Nb}_{6} \mathrm{Cl}_{12} \mathrm{O}_{2}$ series $^{27,39}(\mathrm{~A}=$ alkaline cations or $\mathrm{In} ; x<1)$ is structurally related to $\mathrm{CsNb}_{6} \mathrm{Cl}_{12} \mathrm{O}_{2}$ with a deficiency on the $\mathrm{A}$ site. $\mathrm{Na}_{0.21} \mathrm{Nb}_{6} \mathrm{Cl}_{10.5} \mathrm{O}_{3}$ is built up from $\mathrm{Nb}_{6} \mathrm{Cl}_{9}^{\mathrm{i}} \mathrm{O}_{3}^{\mathrm{i}} \mathrm{Cl}_{3}^{\mathrm{a}} \mathrm{O}_{3}^{\mathrm{a}}$ units ( 3 inner and 3 apical oxygens among the 18 ligands). ${ }^{30}$ They are interconnected by double $\mathrm{O}^{\mathrm{i}-\mathrm{a}} / \mathrm{O}^{\mathrm{a}-\mathrm{i}}$ bridges to form a $\mathrm{Nb}_{6} \mathrm{Cl}_{9}^{\mathrm{i}} \mathrm{O}_{3 / 2}^{\mathrm{i}-\mathrm{a}} \mathrm{Cl}_{3}^{\mathrm{a}} \mathrm{O}_{3 / 2}^{\mathrm{a}-\mathrm{i}} 2-\mathrm{D}$ pseudo-layer. The layers are linked by the 3 remaining apical chlorine atoms to form a $\mathrm{Nb}_{6} \mathrm{Cl}_{9}^{\mathrm{i}} \mathrm{O}_{3 / 2}^{\mathrm{i}-\mathrm{a}} \mathrm{Cl}_{3 / 2}^{\mathrm{a}-\mathrm{a}} \mathrm{O}_{3 / 2}^{\mathrm{a}-\mathrm{i}}$ 3-D framework. $\mathrm{Ti}_{2} \mathrm{Nb}_{6} \mathrm{O}_{12}{ }^{31}$ and $\mathrm{Na}_{2}\left(\mathrm{Sc}_{4} \mathrm{Nb}_{2}\right)\left(\mathrm{Nb}_{6} \mathrm{O}_{12}\right)_{3}{ }^{32}$ are based on $\mathrm{Nb}_{6} \mathrm{O}_{12}^{\mathrm{i}} \mathrm{O}_{6}^{\mathrm{a}}$ units that are interconnected by double $\mathrm{O}^{\mathrm{i}-\mathrm{a}} / \mathrm{O}^{\mathrm{a}-\mathrm{i}}$ to form a 3-D framework with the $\mathrm{Nb}_{6} \mathrm{O}_{6}^{\mathrm{i}} \mathrm{O}_{6 / 2}^{\mathrm{i}-\mathrm{a}} \mathrm{O}_{6 / 2}^{\mathrm{a}-\mathrm{i}}$ developed formula.

34 R. Chevrel and M. Sergent, in Superconductivity in Ternary Compounds Vol. I, ed. M. B. Maple and O. Fischer, Springer-Verlag, Berlin/ Boston, 1982, vol. 1, p. 25.

35 J. W. Benson, G. L. Schrader and R. J. Angelici, J. Mol. Catal. A. Chem., 1995, 96, 283.

36 D. Aurbach, G. S. Suresh, E. Levi, A. Mitelman, O. Mizrahi, O. Chusid and M. Brunelli, Adv. Mater., 2007, 19, 4260.

37 R. W. Nunes, I. I. Mazin and D. J. Singh, Phys. Rev. B: Condens. Matter, 1999, 59, 7969.

38 See for example: (a) P. Pyykkö, Chem. Rev., 1988, 88, 563; (b) T. Hughbanks, Prog. Solid State Chem., 1989, 19, 329; (c) Z. Lin and I. D. Williams, Polyhedron, 1996, 15, 3277; (d) N. Kaltsoyannis, J. Chem. Soc., Dalton Trans., 1997, 1; (e) Z. Lin and M.-F. Fan, Struct. Bonding, 1997, 87, 35.

39 E. V. Anokhina, C. S. Day, H.-J. Meyer, M. Strobele, S. M. Kauzlarich, H. Kim, M.-H. Whangbo and A. Lachgar, J. Alloys Compd., 2002, 338, 218.

40 F. Ogliaro, S. Cordier, J.-F. Halet, C. Perrin and J.-Y. Saillard, Inorg. Chem., 1998, 37, 6199.

41 S. Cordier, C. Perrin and M. Sergent, Mater. Res. Bull., 1996, 31, 683.

42 S. Cordier, C. Perrin and M. Sergent, Mater. Res. Bull., 1997, 32, 25 .

43 J. C. Bonner and M. E. Fisher, Phys. Rev., 1964, 135, A640.

44 O. Kahn, Molecular Magnetism, Wiley-VCH, New York, 1993.

45 J. Xue, Q. Zhou, H. Suzuki and S. Misawa, J. Low Temp. Phys., 2000, 121, 127.

46 J. G. Converse and R. E. McCarley, Inorg. Chem., 1971, 9, 1361.

47 MATLAB version 7.7, MathWorks Inc., Natick, Massachusetts, 2008

48 (a) M.-H. Whangbo, H.-J. Koo and D. Dai, J. Solid State Chem., 2003, 176, 417; (b) M.-H. Whangbo, D. Dai and H.-J. Koo, Solid State Sci., 2005, 7, 827.

49 J. Köhler, A. Simon and M. H. Whangbo, Z. Anorg. Allg. Chem., 2009, 635, 2396.

50 B. Perić, S. Cordier, J. Cuny, R. Gautier, T. Guizouarn and P. Planinić, Chem.-Eur. J., 2011, 17, 6263.

51 (a) L. Noodleman, J. Chem. Phys., 1981, 74, 5737; (b) L. Noodleman and E. R. Davidson, Chem. Phys., 1986, 109, 131; (c) L. Noodleman and D. A. Case, Adv. Inorg. Chem., 1992, 38, 423; (d) R. Caballol, O. Castell, F. Illas, I. de P. R. Moreira and J. P. Malrieu, J. Phys. Chem. A, 1997, 101, 7860 .

52 (a) O. K. Andersen, Phys. Rev. B: Solid State, 1975, 12, 3060; (b) O. K. Andersen, Europhys. News, 1981, 12, 4; (c) O. K. Andersen, in The Electronic Structure Complex Systems, ed. P. Phariseau and W. M. Temmerman, Plenum Publishing Corporation, New York, 1984; (d) O. K. Andersen and O. Jepsen, Phys. Rev. Lett., 1984, 53, 2571; (e) O. K. Andersen, O. Jepsen and M. Sob, in Electronic Band Structure and its Applications, ed. M. Yussouf, Springer-Verlag, Berlin, 1986; (f) H. L. Skriver, The LMTO Method, Springer-Verlag, Berlin, 1984.

53 U. von Barth and L. Hedin, J. Phys. C: Solid State Phys., 1972, $5,1629$.

54 O. Jepsen and O. K. Andersen, Z. Phys. B: Condens. Matter, 1995, 97, 35 .

55 P. E. Blöchl and O. K. Andersen, Phys. Rev. B: Condens. Matter, $1994,49,16223$. 
56 R. Dronskowski and P. E. Blöchl, J. Phys. Chem., 1993, 97, 8617.

57 F. Boucher and R. Rousseau, Inorg. Chem., 1998, 37, 2351.

58 (a) G. te Velde, F. M. Bickelhaupt, E. J. Baerends, C. Fonseca Guerra, S. J. A. van Gisbergen, J. G. Snijders and T. Ziegler, J. Comput. Chem., 2001, 22, 931; (b) C. Fonseca Guerra, J. G. Snijders, G. te Velde and E. J. Baerends, Theor. Chem. Acc., 1998, 99, 391; (c) SCM, ADF2009.01, Theoretical Chemistry, Vrije Universiteit, Amsterdam (Netherlands).
59 J. P. Perdew, K. Burke and M. Ernzerhof, Phys. Rev. Lett., 1996, 77, 3865.

60 J. P. Perdew and Y. Wang, Phys. Rev. B: Condens. Matter, 1992, 45, 13244.

61 E. J. Baerends, D. E. Ellis and P. Ros, Chem. Phys., 1973, 2, 41.

62 (a) E. van Lenthe, E. J. Baerends and J. G. Snijders, J. Chem. Phys., 1993, 99, 4597; (b) E. van Lenthe, E. J. Baerends and J. G. Snijders, J. Chem. Phys., 1994, 101, 9783. 